\title{
UJI SENSORI, FISIK DAN KIMIA KERUPUK IKAN DENGAN PENAMBAHAN KONSENTRASI DAGING IKAN GABUS (Channa striata) YANG BERBEDA
}

Sensory, Physical and Chemistry Analysis of Crackers with Different Additional Meat Concentration of Snakehead Fish (Channa striata)

\author{
Tresia Natalia1*, Hermanto2, Kobajashi T. Isamu1 \\ 1Jurusan Teknologi Hasil Perikanan, Fakultas Perikanan dan IImu Kelautan Universitas Halu Oleo, Kendari, \\ Sulawesi Tenggara, Indonesia \\ 2Jurusan Ilmu dan Teknologi Pangan, Fakultas Pertanian Universitas Halu Oleo, Kendari, Sulawesi Tenggara, \\ Indonesia \\ *Email korespondensi: tresia021@gmail.com (Telp: +6282346141437) \\ Diterima: 6 Agustus Oktober/ Disetujui 3 September 2019
}

Cara sitasi: Natalia T, Hermanto, Isamu KT. 2019. Uji sensori, fisik dan kimia kerupuk ikan dengan penambahan konsentrasi daging ikan gabus (Channa striata) yang berbeda. Jurnal Fish Protech. 2(2):157-164.

\begin{abstract}
The aim of this study was to determine the effect of the addition of Catfish (Channa striata) meat concentration which was different from the parameters observed in sensory tests (appearance, smell, taste, and crispnes), physical test (volume of development) and chemical tests (water content, ash content, protein content and carbohydrate content) and in crackers. This study uses a Completely Randomized Design (CRD) which consists of three treatments namely treatment A (DG 30\%), B (DG 40\%) and C (DG 50\%) and replications three times. Observation data were analyzed using ANOVA (Analysis of Variance) at the level of $95 \%$, if there were significant differences $(P>0.05)$ then further testing was carried out with DMRT (Duncan Multiple Range Test) at 95\% significance level. The results obtained showed that adding catfish meat to fish crackers had no significant effect on sensory values which included appearance, smell, and taste, but sensory crispness had a significant effect The best results for sensory assessment were found in treatment $C$ where the value appearance 7,4, smell, 7,7, taste 7,4 and crispness 4,4 was in treatment $A$. The physical test results of the development volume show the best value of treatment $A$ with a development volume of $140 \%$. The best treatment for chemical tests was in treatment $C$ with a water content of $10,90 \%$ and protein content of $14,10 \%$. While the best ash content of $2,35 \%$ and carbohydrate content of $43,82 \%$ in treatment $A$.
\end{abstract}

Keywords: catfish (Channa striata), crackers, chemical test, physical and sensory

\section{ABSTRAK}

Tujuan penelitian ini adalah untuk mengetahui pengaruh penambahan konsentrasi daging ikan gabus (Channa striata) yang berbeda terhadap parameter yang diamati pada uji sensori (kenampakan, bau, rasa dan kerenyahan), uji fisik (volume pengembangan) dan uji kimia (kadar air, kadar abu, kadar protein dan kadar karbohidrat) pada kerupuk ikan. Penelitian ini menggunakan Rancangan Acak Lengkap (RAL) yang terdiri dari tiga perlakuan yaitu perlakuan $\mathrm{A}$ (daging ikan gabus 30\%), B (daging ikan gabus $40 \%$ ) dan C (daging ikan gabus $50 \%$ ) dan ulangan sebanyak tiga kali. Data hasil pengamatan dianalisa menggunakan ANOVA (Analysis of Variance) pada taraf $95 \%$, apabila terdapat beda nyata $(P>0,05)$ maka dilakukan uji lanjut dengan uji DMRT (Duncan Multiple Range Test) pada taraf nyata $95 \%$. Hasil penelitian yang diperoleh menunjukkan bahwa penambahan daging ikan gabus terhadap kerupuk ikan memberikan pengaruh tidak nyata terhadap nilai sensori yang meliputi kenampakan, bau, dan rasa, tetapi pada sensori kerenyahan memberikan pengaruh nyata. Hasil terbaik untuk penilaian sensori terdapat pada perlakuan $C$ dimana memiliki nilai kenampakan 7,4, bau 7,7, rasa 7,4 sedangkan perlakuan terbaik untuk kerenyahan 4,4 terdapat pada perlakuan A. Perlakuan terbaik pada uji fisik volume pengembangan menunjukkan nilai terbaik yaitu perlakuan A dengan nilai volume pengembangan $140 \%$. Perlakuan terbaik pada uji kimia terdapat pada perlakuan C dengan nilai kadar air 10,90\%, kadar protein 14,10\%, sedangkan perlakuan terbaik untuk kadar abu 2,35\% dan kadar karbohidrat $43,82 \%$ terdapat pada perlakuan A.

Kata kunci: (Channa striata), Ikan gabus, kerupuk, uji kimia, fisik, dan sensori 


\section{PENDAHULUAN}

Indonesia sebagai negara kepulauan memilki zona maritim yang sangat luas, yaitu 5,8 juta $\mathrm{km} 2$ yang terdiri atas perairan kepulauan 2,3 juta $\mathrm{km} 2$, laut teritorial 0,8 juta $\mathrm{km} 2$ dan perairan Zona Ekonomi Eksklusif 2,7 juta km2. Indonesia memiliki potensi perikanan tangkap sebesar 6,4 juta ton per tahun. Baru termanfaatkan sebesar $63,5 \%$ atau sebesar 4,1 juta ton per tahun. Tingkat pemanfaatan (exploitation rate) terlihat masih jauh dari potensi lestarinya (Departemen Kelautan dan Perikanan, 2009).

Sulawesi Tenggara merupakan salah satu Provinsi di Indonesia yang memiliki potensi ikan air tawar yang cukup besar. Salah satu daerah di Sulawesi Tenggara yang memiliki potensi budidaya ikan air tawar adalah Kabupaten Konawe dengan data produksi budidaya perikanan mencapai 11666,02 ton/tahun dengan asumsi ikan gabus sebesar 25,15 ton/tahun (BPS, 2018). Sedangkan untuk potensi budidaya ikan air tawar yang dimiliki Sulawesi Tenggara adalah sebesar 31.231 hektar (Ditjen Budidaya Kementerian Kelautan dan Perikanan, 2014).

Ikan gabus merupakan jenis ikan bernilai ekonomis penting yang mengandung protein $17,61 \%$, lemak 1,34 \%, Vitamin A $45 \mathrm{Mg}$ dan Vitamin B 0,04 Mg dalam $100 \mathrm{~g}$ (Ansar ,2010). Ikan gabus memiliki daging kenyal, putih, tidak menimbulkan alergi sehingga dapat dibuat kerupuk dengan rasa enak/gurih (Fajri, 1997).

Pengawetan ikan secara tradisional telah dilakukan saat ini dengan tujuan mengurangi kadar air dalam tubuh ikan, sehingga tidak dapat memberikan kesempatan pada bakteri (mikroba) untuk hidup dan berkembang (Berhimpon et al., 2002). Cara untuk menjaga mutu hasil perikanan diperlukan usahausaha pengolahan dan pengawetan, baik secara modern maupun tradisional, salah satu produk olahan ikan yang dilakukan adalah mengolahnya menjadi kerupuk.

Kerupuk adalah salah satu produk olahan tradisional yang digemari oleh masyarakat Indonesia. Kerupuk memiliki tekstur yang renyah dan garing yang dapat dikonsumsi sebagai makanan selingan maupun sebagai variasi dalam lauk pauk (Koswara, 2009).

\section{METODE PENELITIAN}

\section{Lokasi Penelitian}

Penelitian ini dilaksanakan di Laboratorium Pengujian dan Laboratorium Pendidikaan Kimia Fakultas Keguruan dan IImu Pendidikan Universitas Halu Oleo (UHO) Kendari.

\section{Alat dan Bahan}

Alat yang digunakan dalam penelitian ini ada 2 macam yaitu alat untuk pengolahan dan alat untuk analisis. Alat pengolahan meliputi: baskom stainless stell, pisau (Lion Star), blender (Miyako), panci (Aluminium Ware), kompor (Rinnai), oven (Memmert un 55), thermometer suhu minyak, dan stopwatch (aplikasi handphone). Alat untuk analisis proksimat meliputi: alat ekstraksi soxhlet (Pyrex), tanur (Nabertherm), gelas piala (Pyrex), gelas ukur (Phyrex), batang pengaduk (lokal), pipet tetes (lokal), pipet mikro (Socorex), corong (Pyrex), tabung reaksi (Pyrex), labu takar (Pyrex), erlenmeyer (Pyrex), buret (Pyrex), desikator (Duran), timbangan analitik (Matrix), cawan petri (Pyrex), penjepit cawan (lokal), gegep (lokal), cawan porselin (Pyrex), cawan aluminium (lokal), botol semprot ( lokal) dan spektofotometer UVVis (WTW).

Bahan yang akan digunakan terdiri atas bahan utama dan bahan pendukung. Bahan utama adalah daging ikan gabus. Bahan pendukung adalah tepung tapioka, telur, garam, bawang putih, air, dan minyak goreng. Bahan kimia untuk analisis kimia adalah aquades, alkohol $80 \%, \mathrm{NaOH}$, reagen biuret, kertas saring, heksan, dan larutan standar protein.

\section{Rancangan Penelitian}

Penelitian ini menggunakan Rancangan Acak Lengkap (RAL) yang terdiri dari 3 perlakuan yaitu $A$ (daging ikan gabus 30\%), B (daging ikan gabus 40\%), dan $C$ (daging ikan gabus 50\%). Masing-masing perlakuan dilakukan tiga kali ulangan, sehingga diperoleh jumlah satuan percobaan sebanyak 9 unit. 


\section{Pembuatan Kerupuk Ikan}

\section{Penyiapan bahan}

Ikan pada penelitian ini menggunakan ikan gabus segar dengan ciri-ciri, masih memiliki organ tubuh yang utuh atau lengkap, bau masih segar, lendir masih banyak, mata masih jernih, insang merah, dan daging ikan masih kenyal saat ditekan menggunakan jari dan ikan gabus ini diambil dari pasar panjang Kota Kendari. Kemudian ikan dibersihkan, dengan air yang bersih, setelah itu dipisahkan antara daging dengan tulangnya. daging ikan gabus yang telah bersih dihaluskan menggunakan meet grinder dan ditimbang sesuai dengan kebutuhan.

\section{Pembuatan adonan}

Pembuatan adonan adalah pencampuran semua bahan hingga homogen. Tepung tapioka, daging ikan gabus, bumbu-bumbu yang sudah di haluskan dan air dicampur dengan tangan, pencampuran ini dilakukan selama $\underline{5}$ menit hingga terbentuk adonan yang homogen.

\section{Pencetakkan}

Setelah proses pembuatan adonan selesai, adonan dicetak menajdi bentuk lontongan (silinder).

\section{Pengukusan}

Adonan dikukus hingga matang selama 3 jam dengan suhu $100 \circ$ C. Untuk mengetahui adonan yang telah dikukus telah matang adonan ditusuk dengan menggunakan lidi, jika adonan masih menempel pada lidi menandakan adonan belum matang dan sebaliknya jika tidak ada adonan yang menempel pada lidi menandakan adonan sudah matang.

\section{Pengirisan}

Setelah adonan selesai dimasak, adonan diangkat dari dalam panci kukusan, kemudian didinginkan selama 24 jam. Setelah dingin adonan yang sudah dikukus diiris dengan ketebalan $2 \mathrm{~mm}$ dengan menggunakan pisau.

\section{Pengeringan}

Pengeringan yang dilakukan dalam penelitian ini adalah dengan menggunakan menggunakan oven selama 24 jam dengan suhu $45_{\circ} \mathrm{C}$. Tujuan pengeringan adalah untuk mengurangi kadar air bahan sampai batas dimana perkembangan mikroorganisme yang dapat menyebabkan pembusukan terhambat, demikian juga perubahanperubahan akibat aktivitas enzim.

\section{Penggorengan}

Menurut Siswantoro (2008), ditinjau dari segi waktu proses pemasakan, penggorengan adalah salah satu cara pemasakan produk pangan yang dilakukan secara cepat, dan cara ini dianggap paling efisien proses transfer panasnya ke produk pangan yang dimasak. Tahap penggorengan ini adalah melakukan penggorengan dengan cara deep fat frying. Kerupuk yang sudah kering digoreng dengan menggunakan minyak goreng. Suhu yang digunakan dalam penggorengan yaitu 120 oC (Alfisyahrica, 2015) selama 10 detik.

\section{Parameter uji}

Uji Sensori (SNI. 01-2346. 2006), Uji Fisik (Volume Pengembangan Zulviani, 2000). Analisis uji kimia meliputi kadar abu (AOAC, 1995), kadar air (AOAC, 1995), kadar protein (AOAC,1995) dan kadar karbohidrat (BPT, 2005) .

\section{Analisis Data}

Data hasil penelitian sensori dianalisis menggunakan sidik ragam Anova. Jika terdapat perbedaan yang sangat nyata kemudian akan diuji lanjut menggunakan uji jarak berganda DMRT (Duncan Multiple Range Test) dengan taraf kepercayaan 95\% ( $a=0,05)$. Data diolah menggunakan aplikasi Microsoft Exel (2010). 


\section{HASIL DAN PEMBAHASAN}

Tabel 1. Rekapitulasi hasil analisis ragam uji sensori.

\begin{tabular}{llll}
\hline Parameter & \multicolumn{3}{c}{ Perlakuan } \\
\cline { 2 - 4 } & $\mathrm{a}$ & $\mathrm{b}$ & $\mathrm{c}$ \\
\hline Kenampakan & 6,96 & 7,69 & 7,81 \\
Bau & 7,0 & 7,5 & 7,7 \\
Rasa & 7,17 & 7,27 & 7,4 \\
Kerenyahan & 4,42 & 3,84 & 3,74 \\
\hline
\end{tabular}

Keterangan: a (daging ikan gabus 30\%), b (daging ikan gabus $40 \%$ ), c (daging ikan gabus (daging ikan gabus 50\%).

Tabel 2. Hasil Uji Fisik

\begin{tabular}{clll}
\hline Parameter & \multicolumn{3}{c}{ Perlakuan } \\
\cline { 2 - 4 } & $\mathrm{a}$ & $\mathrm{b}$ & $\mathrm{c}$ \\
\hline Volume & 10,90 & 8.28 & 8.11 \\
pengembangan & & & \\
\hline
\end{tabular}

Keterangan: a (daging ikan gabus 30\%), b (daging ikan gabus $40 \%$ ), c (daging ikan gabus (daging ikan gabus $50 \%$ ).

Tabel 3. Hasil Analisis Kandungan Kimia

\begin{tabular}{llll}
\hline \multirow{2}{*}{ Parameter } & \multicolumn{3}{c}{ Perlakuan } \\
\cline { 2 - 4 } & \multicolumn{1}{c}{$\mathrm{a}$} & \multicolumn{1}{c}{$\mathrm{b}$} & \multicolumn{1}{c}{$\mathrm{c}$} \\
\hline Kadar air (\%) & 10,90 & 8.28 & 8.11 \\
Kadar abu(\%) & 1,61 & 1,99 & 2,36 \\
Kadar protein(\%) & 10,42 & 12,46 & 14,10 \\
Kadar & 43,82 & 42,19 & 35,24 \\
karbohidrat(\%) & & &
\end{tabular}

Keterangan: a (daging ikan gabus 30\%), b (daging ikan gabus $40 \%$ ), c (daging ikan gabus (daging ikan gabus 50\%).

\section{Uji sensori}

\section{Kenampakan}

Berdasarkan hasil nilai rata - rata kerupuk dengan penambahan konsentrasi daging ikan gabus menunjukkan nilai tertinggi pada perlakuan $C$ dengan 7,4 dan nilai terendah pada perlakuan $A$ dengan nilai 6,9. Hal ini diduga karena bertambahnya konsentrasi daging ikan gabus sehingga menyebabkan kenampakan kerupuk ikan gabus yang dihasilkan memiliki permukaan utuh, rapih dan ketebalan kurang rata.
Kenampakan kerupuk dipengaruhi ikan gabus yang digunakan, semakin banyak ikan gabus yang digunakan, kenampakan kerupuk ikan gabus yang dihasilkan lebih memiliki permukaan yang halus. Hal ini diduga ikan gabus segar menggandung protein $25,2 \%$. Protein daging ikan gabus memiliki gugus hidrofil lebih besar dibandingkan tepung sagu sehingga tingkat penyerapan air kerupuk mentah lebih besar. Pada proses penggorengan air yang terikat pada kerupuk akan menguap dan akan digantikan oleh minyak dan menyebabkan permukaan kerupuk lebih halus (Supartono, 2000).

Adanya penurunan kesukaan kenampakan kerupuk ikan gabus pada perlakuan A dengan nilai 6,9 diduga karena konsentrasi tepung tapioka lebih banyak sehingga permukaan kurang halus. Menurut penelitian Layla (2014) Adanya penurunan kesukaan kenampakan kerupuk ikan gabus dari dari formula $A$ perbandingan tepung sagu dan ikan gabus (50:50) dan B (70:30), disebabkan karena bertambahnya konsentrasi tepung sagu yang digunakan sehingga amilopektin yang terdapat di formula A dan B lebih tinggi dibandingkan dengan formula $C$. Akibat hal tersebut, kerupuk formula A (50:50) dan B (70:30), pada saat penggorengan menyerap minyak lebih banyak bandingkan formula $C(30: 70)$, sehingga kenampakan kerupuk ikan gabus kurang baik.

\section{Bau}

Berdasarkan hasil nilai rata - rata kerupuk dengan penambahan konsentrasi daging ikan gabus menunjukkan nilai tertinggi pada perlakuan $\mathrm{C}$ dengan nilai 7,7 dan nilai terendah pada perlakuan $A$ dengan nilai 7,0 . Hal ini diduga karena konsentrasi daging ikan pada perlakuan $\mathrm{C}$ lebih banyak sehingga dapat meningkatkan nilai bau kerupuk ikan gabus tetapi tidak memberikan pengaruh nyata dengan kriteria bau daging ikan gabus. Menurut Suseno (2004), menyatakan bahwa penambahan daging ikan nilem (Ostheochilus hasselti) pada pembuatan kerupuk yang disubstitusi dengan tepung tapioka, peningkatan aroma berasal dari ikan yang digunakan. Konsentrasi daging ikan nilem yang ditambahkan dapat 
menyebabkan aroma kerupuk mempunyai aroma khas kerupuk ikan. Adanya aroma khas disebabkan oleh kandungan protein yang terurai menjadi asam amino khususnya asam glutamat akan menimbulkan rasa dan aroma yang lezat.

Penurunan nilai bau pada perlakuan $A$ dengan nilai7,0 diduga karena konsentrasi tepung tapioka lebih banyak, sehingga bau daging ikan gabus kurang spesifik. Hal ini sesuai dengan penelitian Layla (2014) bahwa perbandingan tepung sagu dan ikan gabus formula $A(50: 50)$ dan $B(70: 30)$ kurang disukai panelis karena tepung sagu menutupi aroma ikan gabus pada produk kerupuk ikan gabus yang dihasilkan sehingga aroma ikan gabus kurang spesifik.

\section{Rasa}

Berdasarkan hasil nilai rata-rata rasa kerupuk dengan penambahan konsentrasi daging ikan gabus menunjukkan nilai tertinggi pada perlakuan $\mathrm{C}$ dengan nilai 7,4 dan nilai terendah pada perlakuan $A$ dengan nilai 7,1. Hal ini diduga karena seiring dengan bertambahnya konsentrasi daging ikan gabus yang diberikan semakin kuat rasanya dan menimbulkan rasa gurih pada kerupuk. rasa gurih pada kerupuk disebabkan oleh kandungan protein yang terdapat pada kerupuk sehingga pada proses pengukusan, protein akan terhidrolisis menjadi asam amino dan salah satu asam amino yaitu asam glutamat dapat menimbulkan rasa yang gurih. Didukung oleh Layla (2014) yang menyatakan bahwa penambahan konsentrasi ikan gabus memberikan pengaruh nyata terhadap rasa kerupuk ikan gabus. Kesukaan panelis terhadap rasa kerupuk ikan gabus mengalami peningkatan seiring bertambahnya konsentrasi daging ikan gabus.

Penurunan nilai rasa pada perlakuan $A$ dengan nilai 7,1 diduga konsentrasi daging ikan yang digunakan sedikit dibanding tepung tapioka yang digunakan sehingga rasa ikan tidak menonjol atau kurang spesifik. Didukung oleh Putra et al. (2015) yang menyatakan bahwa pembuatan kerupuk dengan penambahan $20 \%$ tepung tulang ikan gabus tanpa penambahan daging ikan gabus menurunkan karakteristik sensori rasa. Didukung Sandriana (2012), terhadap penambahan tepung sagu molat $(M$. sagus Rottb) sebagai bahan pengikat pada kerupuk mengemukakan bahwa, penggunaan konsentrasi tepung sagu $80 \%$ dan udang $40 \%$, rasa udang ditutupi oleh tepung sagu yang digunakan. Dan Menurut Subagio (2006), pada proses pengukusan granula pati sagu akan mengalami hidrolisis menghasilkan monosakarida sebagai bahan baku penghasil asam-asam organik, terutama asam laktat. Senyawa asam laktat akan bercampur dengan ikan, ketika dilakukan pengukusan tepung sagu akan menghasilkan aroma dan cita rasa khas yang dapat menutupi aroma dan cita rasa dari ikan.

\section{Kerenyahan}

Berdasarkan hasil nilai rata-rata kerenyahan kerupuk dengan penambahan konsentrasi daging ikan gabus menunjukkan nilai tertinggi pada perlakuan $A$ dengan nilai 4,4 dan nilai terendah pada perlakuan $C$ dengan nilai 3,7 . Hal ini dikarenakan konsentrasi daging ikan dan tepung tapioka pada kerupuk. Semakin tinggi konsentrasi penambahan tepung tapioka pada kerupuk, maka kerupuk akan semakin renyah. Didukung oleh Thaha et al. (2018) yang menyatakan bahwa perlakuan kontrol memberikan nilai tertinggi terhadap nilai kerenyahan diikuti oleh penambahan ikan malaja $15 \%$. Tepung tapioka merupakan salah satu tepung yang memiliki pati cukup baik. Pati mempunyai dua komponen utama yaitu amilosa (fraksi larut) dan amilopektin (fraksi tidak larut).

\section{Penurunan kerenyahan pada perlakuan $\mathrm{C}$} dengan nilai 3,4 diduga karena peningkatan konsentrasi daging ikan gabus yang ditambahkan. Menurut Istanti (2005) kandungan protein yang tinggi dapat menyebabkan kantong-kantong udara kerupuk yang dihasilkan semakin kecil karena padatnya kantong-kantong udara tersebut terisi oleh bahan lain yaitu daging ikan yang banyak mengandung protein sehingga dapat menyebabkan daya kembang semakin kecil yang akhirnya dapat menyebabkan kerenyahan semakin menurun. 


\section{Uji fisik}

\section{Volume Pengembangan}

Berdasarkan hasil uji fisik kerupuk ikan gabus, nilai rata-rata volume pengembangan tertinggi pada perlakuan A yaitu $140 \%$, sedangkan nilai terendah pada perlakuan $\mathrm{C}$ yaitu $76 \%$. Hal ini diduga karena penambahan konsentrasi daging ikan gabus dan konsentrasi tepung tapioka menyebabkan volume pengembangan semakin tinggi. Didukung oleh Zulfahmi (2014) menyatakan bahwa penambahan daging ikan tenggiri menghasilkan daya kembang sebesar $\pm 24,14 \%$ kontrol, dan perlakuan 1:1, 1,5:1, dan 1:2 rata-rata sebesar $\pm 22,26 \%$ dimana kontrol mendapatkan nilai daya kembang paling besar karena dalam pembuatan kerupuk tanpa ditambahkan ikan, sehinggaa amilopektin dapat mengembang maksimal. Hasil ini menunjukkan semakin besar kandungan ikan yang ditambahkan dalam kerupuk ikan menyebabkan daya kembang kerupuk menurun. Jika dibandingkan dengan daya kembang kerupuk komersial pada penelitian Huda et al. (2010) menyebutkan bahwa daya kembang kerupuk pada perlakuan sesuai dengan daya kembang kerupuk komersial.

Daya kembang kerupuk komersial berada diantara 38\% - 145\%. Menurut Kusumaningrum (2011) perbedaan daya kembang menujukan bahwa semakin banyak kandungan amilopektin dalam kerupuk ikan maka daya kembangnya akan semakin besar. Hal ini karenabangunan amilopektin kurang kompak dan kurang menahan pengembangan volume massa sebelum penggorengan. Kandungan amilopektin berasal dari tepung tapioka, oleh karena itu, semakin besar kandungan tepung tapioka dalam kerupuk ikan menyebabkan daya kembang yang semakin besar.

Penurunan volume pengembangan pada $A$ perlakuan $C$ dengan nilai $76 \%$, hal ini diduga karena penambahan daging ikan gabus dan tepung tapioka.. Tingginya kadar protein akan menurunkan pengembangan yang disebabkan adanya sifat viskoelastisitas dan crosslinking antara pati dan protein sehingga kerupuk menjadi rapat dan sukar mengembang saat di goreng (Linardi et al., 2013). Menurut Molerman (2014) semakin banyak penambahan bukan pati maka semakin kecil pengembangan kerupuk pada saat digoreng, dimana tingkat pengembangan dapat menentukan kerenyahan pada kerupuk.

\section{Uji Kimia}

\section{Kadar Air}

Berdasarkan hasil nilai rata-rata kadar air kerupuk dengan penambahan konsentrasi daging ikan gabus menunjukkan nilai tertinggi pada perlakuan $\mathrm{A}$ dengan nilai 10,90 dan nilai terendah pada perlakuan C dengan nilai 8,11 hasil ini sesuai dengan SNI 012713-2009 tentang kerupuk, ikan dimana kadar air maksimal dalam kerupuk ikan adalah $12 \%$. Kadar air cenderung menurun seiring dengan bertambahnya jumlah konsentrasi daging ikan gabus yang digunakan. Hal ini sesuai dengan Deborah et al. (2016) yang menyatakan bahwa dengan bertambahnya konsentrasi tepung tulang ikan pada kerupuk menyebabkan peningkatan kadar air.

Hasil analisis kandungan air mengalami penurunan sejalan dengan penambahan protein, abu dan lemak, karena selama proses pengeringan molekul-molekul air yang terikat akan dilepaskan oleh protein, pernyataan ini dikuatkan oleh Afrila dan Budi (2011), selama pengeringan berlangsung terjadi pelepasan molekul air oleh protein, lemak dan abu daging sehingga konsentrasi protein, lemak dan abu daging meningkat.

\section{Kadar Abu}

Berdasarkan hasil nilai rata-rata kadar abu kerupuk dengan penambahan konsentrasi daging ikan gabus menunjukkan nilai tertinggi pada perlakuan $\mathrm{C}$ dengan nilai 2,35 dan nilai terendah pada perlakuan A dengan nilai 1,60. Hal ini diduga karena konsentrasi daging ikan dan tepung tapioka yang ditambahkan. Hal ini sesuai dengan penelitian Engelen dan Angelia (2015) semakin banyak penambahan tepung talas pada setiap perlakuan akan berpengaruh pada nilai rata-rata kerupuk ikan lele. Didukung oleh penelitian Huda et al.(2009) dimana konsentrasi kadar abu kerupuk ikan meningkat sejalan penambahan daging ikan. Hasil penelitian ini lebih tinggi dari Standar SNI 01-2713-1999 kerupuk ikan maksimal 1\%. Dan 
menurut King (2002) dalam Huda et al. (2010) bahwa jenis ikan yang ditambahkan dalam kerupuk ikan menyebabkan perbedaan kadar abu, dan semakin banyak kandungan ikan dalam kerupuk ikan maka kandungan kadar abu semakin meningkat.

\section{Kadar Protein}

Berdasarkan hasil nilai rata-rata kadar protein kerupuk dengan penambahan konsentrasi daging ikan gabus menunjukkan nilai tertinggi pada perlakuan $\mathrm{C}$ dengan nilai 14,10 dan nilai terendah pada perlakuan A dengan nilai 10,41 . Perbedaan kadar protein antara perlakuan diduga disebabkan oleh bahan utama kerupuk yaitu daging ikan gabus dan tepung tapioka. Perbandingan daging ikan gabus dan tepung tapioka berpengaruh terhadap kadar protein kerupuk. Kadar protein kerupuk semakin meningkat seiring dengan bertambahnya jumlah konsentrasi daging ikan gabus. Penelitian ini sesuai dengan standar SNI 01-27131999 tentang kerupuk ikan dengan kadar protein minimal $5 \%$. Kandungan protein dalam penelitian ini lebih besar jika dibandingkan dengan kadar protein kerupuk komersial pada penelitian Huda et al. (2010) kadar protein kerupuk komersial berada dalam kisaran $5,53 \%$ sampai $16.17 \%$.

Penurunan nilai kadar protein kerupuk ikan gabus pada perlakuan A dengan nilai 10,41 diduga karenajumlah konsentrasi daging ikan yang ditambahkan sedikit dan juga disebabkan oleh denaturasi protein. Menurut Winarno (2008) menyatakan bahwa denaturasi protein dapat dilakukan dengan berbagai cara yaitu oleh panas, $\mathrm{pH}$, bahan kimia, mekanik, dan sebagainya. Menurut Meilani (2005) menyatakan bahwa denaturasi protein dapat terjadi karena beberapa faktor penting antara lain pemanasan, $\mathrm{pH}$, asam, basa, garam, logam berat, sifat permukaan, dan senyawa-senyawa seperti urea dan etanol.

\section{Kadar Karbohidrat}

Berdasarkan hasil nilai rata-rata kadar karbohidrat kerupuk dengan penambahan konsentrasi daging ikan gabus menunjukkan nilai tertinggi pada perlakuan $A$ dengan nilai 43,82 dan nilai terendah pada perlakuan $C$ dengan nilai 35,24 . Hal ini diduga karena konsentrasi tepung tapioka lebih banyak dibanding dengan konsentrasi daging ikan yang ditambahkan. Didukung penelitian Zulfahmi (2014) hasil kadar karbohidrat pada perlakuan tanpa perlakuan (kontrol) diperoleh hasil yang paling tinggi, karena tidak adanya tambahan daging ikan, sehingga sebagian besar kandungan karbohidratnya diperoleh dari tepung tapioka. Tepung tapioka sendiri mempunyai kandungan karbohidrat yang cukup tinggi yaitu sekitar 86,9 \% (Suprapti, 2005). Menurut Putra et al. (2015) semakin tinggi tepung tulang yang ditambahkan kedalam adonan kerupuk, maka kandungan karbohidratnya semakin rendah

\section{KESIMPULAN}

Berdasarkan hasil dan pembahasan maka dapat disimpulkan sebagai berikut :

1. Penambahan konsentrasi daging ikan gabus pada parameter sensori berpengaruh tidak nyata terhadap kenampakan, bau, dan rasa dengan nilai tertinggi $7,4,7,7,7,4$, dan kerenyahan berpengaruh nyata dengan nilai tertinggi 4,4 .

2. Penambahan konsentrasi daging ikan gabus pada parameter fisik yaitu daya kembang kerupuk ikan gabus berpengaruh sangat nyata dengan nilai tertinggi $140 \%$ pada penambahan konsentrasi daging ikan 30\%.

3. Penambahan konsentrasi daging ikan gabus terhadap parameter kimia yaitu kadar air, kadar abu, dan kadar protein tidak berpengaruh nyata dengan nilai tertinggi $10,90 \%, 2,35 \%$, dan $14,10 \%$. Kadar karbohidrat kerupuk ikan gabus berpengaruh nyata dengan nilai tertinggi $43,82 \%$.

\section{DAFTAR PUSTAKA}

Alfisyarica. 2015. Variasi Bagian Telur Dan Presentase Dengan Daging Ikan Pada Proses Pengolahan Amplang Ikan Lele (Clarias gariepinus). [Skripsi] Jurusan Teknologi Hasil Pertanian. Fakultas Teknologi Pertanian. Universitas Jember.

Badan Pusat Statistik Sulawesi Tenggara,2018. 
"Sulawesi Tenggra Dalam Angka" Pemerintah Provinsi Sulawesi Tenggara, Kendari.

Deborah T. Afrianto E. Pratama RI. 2016. Fortifikasi Tepung Tulang Julung-Julung Sebagai Sumber Kalsium Terhadap Tingkat Kesukaan Kerupuk.Jurnal Perikanan Kelautan. 7(1) : 4853

Engelen, A. Angelina.O.I. Kerupuk Ikan Lele (Clarias sp) dengan Subtitusi Tepung Talas (Colocasia esulental L. schoott). Jurnal technology 5(2):34-43.

Fajri.M.Y.1997. Kajian Mutu Kerupuk dari Ikan Gabus (Channa striata). Skripsi. Fakultas Teknologi Pertanian, Institut Pertanian Bogor.

Huda, N, Ang L. L, Chung X. Y. and Herpandi. 2010. Chemical Composition, Colour and Linear Expansion Properties of Malaysian Commercial Fish Cracker Keropok. Asian Journal of Food and Agro-Industry 3 (05), 473482 ISSN 1906-3040.

Laiya, N. R. M, Harmain dan Yusuf, N. 2014.Formulasi Kerupuk Ikan Gabus Yang Disubstitusi Dengan Tepung Sagu.IImiah Perikanan dan Kelautan 2 (2) 81- 87.

Nendissa, Sandriana J. 2009. Pemanfaatan Tepung Sagu Molat (M. sagus rottb) dan Udang Sebagai Bahan Campuran Pembuatan Kerpuk. Jurnal Ekologi dan Sains Vol. 1(1).

Nurman, Gusliko. 2014. Rasio Tepung Sagu dan Ikan Motan (Thynnichthys Polylepis) Terhadap Karakteristik Kerupuk. Vol. 16 No. 2 : 17-25.

Purwani, E dan Hapsari, S. W. N. 2011. Pengaruh Ekstrak Jahe (Zingiber officinale) Terhadap Penghambatan Mikroba Perusak Pada Ikan Nila (Oreochromis niloticus). [Jurnal] Kesehatan, ISSN 1979-7621, Vol. 4, N0.1, Juni 2011: 80-91.

Putra, M.R.A. Nopianti. R. Herpandi. 2015. Fortifikasi Tepung Tulang Ikan Gabus (Channa striata) Pada Kerupuk Sebagai Sumber Kalsium. Fish Technology 4(2):128-139.

Standar Nasional Indonesia 01-2713. 1999. Kerupuk Ikan. Dewan standarisasi nasional. Jakarta: Departemen Perindustrian.

Standar Nasional Indonesia. 3451:2011. Tepung Tapioka. Jakarta : Badan Standardisasi Nasional.

Suseno, S. H, Suptijah P, dan Wahyuni D. S.2004. Pengaruh Penambahan Daging Lumat Ikan Nilem (Ostheochilus hasselti) pada Pembuatan Simping sebagai Makanan
Cemilan. Buletin Teknologi Hail Perikanan. 7 (1).

Suwardian. 2005. Pemanfaatan gonad cumi dan tepung tapioka sebagai bahan pembuatan kerupuk teluk cumi [skripsi]. Bogor: Departemen Teknologi Hasil Perikanan, Fakultas Perikanan dan Ilmu Kelautan, Institut Pertanian Bogor.

Thaha, R.A. Zainal. Hamid K. Ramadhan. D.N. Nasrul. 2018. Analisis Proksimat dan Organoleptik Penggunaan Ikan Malaja Sebagai Pembuatan Kerupuk Kemplang. Jurnal Media Kesehatan Masyarakat Indonesia. Vol 14. No.1.Th 2018.

Winarno, F.G.1992. Kimia Pangan dan Gizi. Jakarta: PT Gramedia PustakaUtama.

Zulfahmi, A. N, Swastawati F dan Romadhon. 2014.Pemanfaatan Daging IkanTenggiri (Scomberomorus commersoni) Dengan Konsentrasi yang Berbeda pada Pembuatan Kerupuk Ikan. Pengolahan dan Bioteknologi Hasil Perikanan Volume 3, Nomer 4, Tahun 2014, Halaman 133-139.

Zulisyanto, D. 2016. Pengaruh Lama Pengukusan Adonan Terhadap Kualitas Fisik Dan Kimia Kerupuk Ikan Lele Dumbo (Clarias Gariepinus). Jurnal Pengolahan dan Bioteknologi Hasil Perikanan. Vol. 5, No. 4 Th, 2016.

Zulviani, R. 2002. Pengaruh Berbagai Tingkat Penggorengan Terhadap Pola pengembangan Kerupuk sagu Goreng [Skripsi]. Bogor: Jurusan Teknologi Pangan Dan Gizi, Industri Pertanian Bogor. 